\title{
A PCR-Based Technique for Detection of Neotyphodium Endophytes in Diverse Accessions of Tall Fescue
}

\author{
Robert P. Doss, USDA-ARS, Horticultural Crops Research Unit, Corvallis, OR 97330, and Department of \\ Horticulture, Oregon State University, Corvallis 97331; Stephen L. Clement, USDA-ARS, Western Regional Plant \\ Introduction Station, Pullman, WA 99164; Srey-Reath Kuy, USDA-ARS, Horticultural Crops Research Unit, \\ Corvallis, OR 97330; and Ronald E. Welty, USDA-ARS, National Forage Seed Production Research Unit (retired), \\ Corvallis, OR 97333
}

\begin{abstract}
Doss, R. P., Clement, S. L., Kuy, S.-R., and Welty, R. E. 1998. A PCR-based technique for detection of Neotyphodium endophytes in diverse accessions of tall fescue. Plant Dis. 82:738-740.

A previously described polymerase chain reaction (PCR)-based method used for detection of Neotyphodium coenophialum in tall fescue detected Neotyphodium endophytes in some, but not all, infected plants from a geographically diverse sample. In the study reported here, a different set of primers, based on intervening sequences of the tubulin 2 gene, were prepared and used for PCR. PCR with these primers yielded the expected 444 base pair amplification product with DNA from 104 of the 106 infected accessions tested. In addition, one accession originally scored as endophyte-free on the basis of a tissue culture test was correctly rated as endophyteinfected using the PCR procedure. Results suggest that primers based on intervening sequences of the tubulin 2 gene can be used for PCR-based detection of Neotyphodium endophytes in tall fescue accessions of diverse origin.
\end{abstract}

Additional keywords: Acremonium, Festuca arundinacea

Tall fescue, Festuca arundinacea, an important forage, pasture, and turf grass (3), is sometimes infected with endophytic fungi that grow asymptomatically within the grass foliage $(1,22)$. These fungi, which were formerly placed in the genus Acremonium, have recently been assigned to the new genus Neotyphodium Glenn, Bacon and Hanlin gen. nov. (11), based on DNA sequence analysis. Molecular analysis has demonstrated that they are descended from fungi of the genus Epichlöe (Ascomycotina, Clavicipitaceae; $16,20,21$ ).

Grasses infected with endophytes can benefit from the association in several ways, including enhancement of vigor, greater drought tolerance, and increased resistance to attack by insects and other herbivores $(20,21)$. Insect resistance is conferred by the presence of toxic alkaloids produced by the fungus that are present in the grass foliage $(20,21)$. Other fungal-derived alkaloids, however, can be

Corresponding author: R. P. Doss

E-mail: dossr@bcc.orst.edu

Technical paper No. 11302 of the Agricultural Experiment Station, Oregon State University.

Accepted for publication 18 March 1998.

Publication no. D-1998-0430-01R

This article is in the public domain and not copyrightable. It may be freely reprinted with customary crediting of the source. The American Phytopathological Society, 1998. harmful to livestock, reducing the forage value of endophyte-infected grass $(20,21)$. Hence, from an agronomic perspective, whether or not a tall fescue genotype is infected with endophyte is an important determinant of end use.

Endophytes can be detected in planta using histochemical $(2,5,17,25)$, immunological $(13,14)$, and tissue culture (8) techniques (10). In addition, we recently described a method for detection of Neotyphodium coenophialum in tall fescue (9) that employed the polymerase chain reaction (PCR; 18). When we attempted to use the PCR-based technique to detect Neotyphodium endophytes in a geographically diverse sample of tall fescue, the diagnostic 1,000 base pair (bp) amplification product was not detected in 3 out of 8 endophyte-infected $(\mathrm{E}+)$ plants. The oligonucleotide primers used with this PCR method were based on the nucleotide sequence of a fragment of genomic DNA present in $N$. coenophialum that had been isolated from "Kentucky 31," a tall fescue cultivar widely grown in the United States. The Neotyphodium endophyte (i.e., $N$. coenophialum) present in this cultivar, and in the other forage-type tall fescues derived from it, is genetically uniform $(4,15,21)$; whereas, as a group, the Neotyphodium endophytes infecting tall fescue are quite diverse (24). Thus, our inability to detect endophytes in some infected plants suggested that the primers used in the original PCR-based detection procedure did not hybridize efficiently with fungal DNA from Neotyphodium endophytes present in some tall fescue accessions of diverse origin. Indeed, many of the Mediterranean accessions examined in this study harbored Neotyphodium isolates that could not be accommodated by the taxon $N$. coenophialum (6) as presently defined (26). The objective of this study was to develop a PCR-based method that would detect symbiotic Neotyphodium endophytes in a diverse sample of tall fescue accessions.

\section{MATERIALS AND METHODS}

Plant materials. The tall fescue accessions used were from the germplasm collection at the Untied States Department of Agriculture-Agricultural Research Service (USDA-ARS), Western Regional Plant Introduction Station, Pullman, Washington. Seed of these accessions was collected during a 1994 plant exploration trip to North Africa and Italy (Sardinia; 6). Fresh tillers of the plants were shipped from Pullman to Corvallis, Oregon on ice. Samples were coded so that personnel carrying out the PCR-based tests were unaware of the endophyte infection status, which had been determined using a tissue culture assay (6).

DNA extraction. DNA was extracted from small cylinders of the basal tissue of grass tillers using the method of Steward and Via (23), with four tillers per extraction $(25$ to $50 \mathrm{mg}$ ). Small plastic pestles fitted to microcentrifuge tubes (Kontes, Vineland, NJ) were used for homogenization. DNA was taken up in either 400 or $100 \mu \mathrm{l}$ of water.

PCR and detection of amplification product. PCR was carried out using the 11-1 and 11-2 primers described previously (9), or two primers (IS-1 and IS-3) based on the nucleotide sequence of introns 1 and 3 of the tubulin 2-4 gene (Tub 2 primers; Table 1). The tubulin 2-4 gene was present in all of the tall fescue endophyte isolates examined by Tsai et al. (24). The PCR reaction volume was $25 \mu \mathrm{l}$, and the composition was as follows: $10 \mathrm{mM}$ TRIS-HCl, pH 8.3; $50 \mathrm{mM} \mathrm{KCl} ; 1.5 \mathrm{mM} \mathrm{MgCl}_{2} ; 200$ $\mu \mathrm{M}$ each deoxynucleotide triphosphate (Promega, Madison, WI); $1.0 \mu \mathrm{M}$ each oligonucleotide primer, 0.625 units Amplitaq DNA polymerase (Applied Biosystems, Foster City, CA), $1 \mu$ DNA extract. 
Reactions were formulated on ice and then held at $94^{\circ} \mathrm{C}$ for $1 \mathrm{~min}$, followed by 35 cycles with a $94^{\circ} \mathrm{C}$ melting temperature for $15 \mathrm{~s}$ and an annealing/reaction temperature of $60^{\circ} \mathrm{C}$ for $1 \mathrm{~min}$ (Coy Thermocycler II, Grass Lake, MI). After cycling, reactions were held at $72^{\circ} \mathrm{C}$ for $10 \mathrm{~min}$ to complete polymerizations. Amplification products were then separated by agarose gel electrophoresis using a $2 \%$ agarose gel (cat no. A 9539, Sigma Chemical Co., St. Louis) with a TRIS-phosphate buffer system, and detected by staining the gel with ethidium bromide (19).

\section{RESULTS AND DISCUSSION}

When a sample of 12 tall fescue plants comprising 2 Kentucky 31 derivatives and 10 accessions from North Africa and Italy (Sardinia) was subjected to the PCR-based detection procedure described previously (9), the diagnostic 1 kilobase $(\mathrm{kb})$ amplification product was not detected with 3 of the 8 E+ plants (Fig. 1). Histological examination (25) confirmed the results from tissue culture, and demonstrated that the PCR-based technique had failed to detect endophytes in some E+ plants (Table 1).

Table 1. Neotyphodium endophyte infection status of 12 tall fescue accessions determined using several diagnostic methods

\begin{tabular}{|c|c|c|c|c|}
\hline Accessions & Tissue culture & Histological & $\begin{array}{c}\text { PCR } \\
(11-1 / 11-2 \text { primers })^{a}\end{array}$ & $\begin{array}{c}\text { PCR } \\
\text { (Tub-2 primers) }^{\mathbf{b}}\end{array}$ \\
\hline $\mathrm{Q} 1^{\mathrm{c}}$ & + & + & + & + \\
\hline $1-16067 \mathrm{~T}$ & + & + & + & + \\
\hline $1-16075 \mathrm{~T}$ & + & + & + & + \\
\hline $4-16003 \mathrm{~T}$ & + & + & - & + \\
\hline $\mathrm{Q}^{\mathrm{c}}$ & - & - & - & - \\
\hline $2-16094 \mathrm{~T}$ & - & - & - & - \\
\hline $2-160036 \mathrm{~T}$ & - & - & - & - \\
\hline $5-16144 \mathrm{~T}$ & - & - & - & - \\
\hline $1-15778 \mathrm{M}$ & + & + & - & + \\
\hline 4-16144S & + & + & + & + \\
\hline $42 \mathrm{~T}$ & + & + & - & + \\
\hline $43 \mathrm{~T}$ & + & + & + & + \\
\hline
\end{tabular}

a PCR = polymerase chain reaction. Primer 11-1, 5'-TCA TAC CGG CTA ACC GGC ATT-3'; primer 11-2, 5'-TGT TAC AGG ATT GGT AGA GGC-3'.

b Tub-2 primers: Primer IS-1, 5'-GGT GTT GAG CCC CCC TGA TTT-3'; primer IS-3, 5'-GTC TCA TCT CCG GGG CGG TAT-3'

${ }^{\mathrm{c}} \mathrm{Q} 1$ and Q2 are Kentucky 31 accessions.
With some endophyte-free (E-) plants, an amplification product with a molecular size slightly greater than the diagnostic 1,000-bp fragment was obtained when an annealing/reaction temperature of $60^{\circ} \mathrm{C}$ was used with the 11-1 and 11-2 primers (Fig. 1). This product, presumably derived as the result of nonspecific priming, disappeared with an annealing temperature of $68^{\circ} \mathrm{C}$.

The PCR technique we employed was developed using primers based on the nucleotide sequence of a fragment of genomic DNA from an endophyte (N. coenophialum) isolated from a Kentucky 31 tall fescue derivative. The failure to detect endophyte in some E+ plants with this method suggested that the primers used did not hybridize with DNA from all of the Neotyphodium endophytes in tall fescue. Accordingly, new primers, based on the intervening sequence of a B-tubulin gene (tub 2-4) that was present in all of the isolates of Neotyphodium spp. from tall fescue examined by Tsai et al (24), were prepared and used for PCR. With these primers, all eight of the endophyte-infected tall fescue accessions in the test sample yielded the expected 444 bp amplification product (Fig. 1, Table 1).

Subsequently, we examined a tall fescue germplasm collection originating from seed collected in the wild from Italy (Sardinia) and North Africa. Of 160 accessions in this collection, 106 were $\mathrm{E}+$, and the PCR method confirmed the endophyte

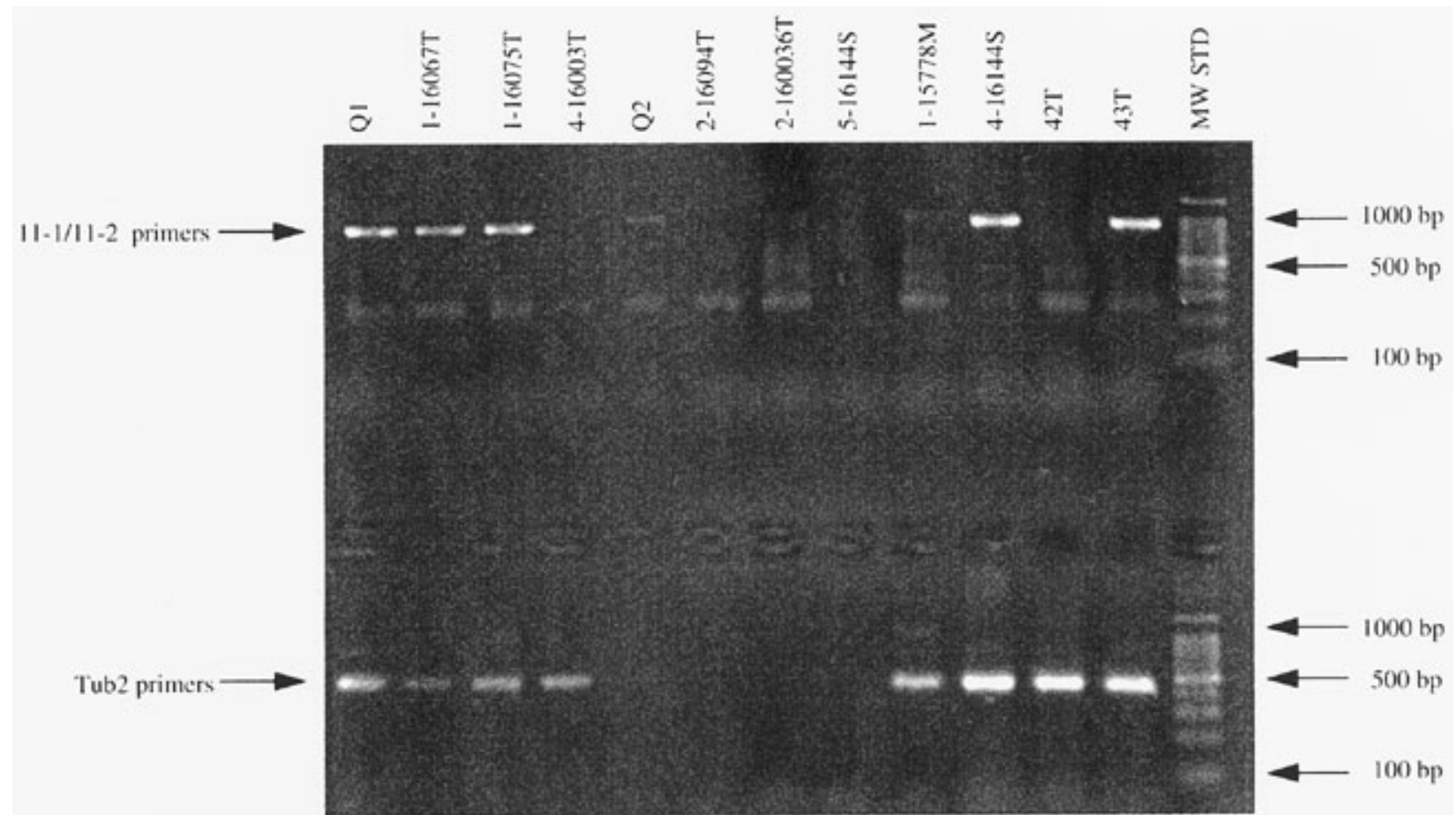

Fig. 1. Ethidium bromide-stained agarose gel showing 1,000 base pair (bp) amplification product obtained using 11-1 and 11-2 primers (upper lanes) and 444 bp product obtained with Tub-2 primers (lower lanes). Tall fescue accession designations are indicated above lanes. Q1 and Q2 are Kentucky 31 derivatives. Molecular weight standards are in rightmost lanes. Note that in some cases with the 11-1 and 11-2 primers and an annealing temperature of $60^{\circ} \mathrm{C}$, nonspecific priming gave rise to amplification products of nearly the same size as the diagnostic product. Such products, which are seen here as weak bands, could be eliminated by increasing the annealing temperature to $68^{\circ} \mathrm{C}$. Tub-2 primers yield more amplification product with the lower annealing temperature than with the higher temperature. 
infection status in all but 3 cases. With one of these (an accession from Sardinia), formerly scored as E-, a diagnostic amplification product was observed, suggesting that the tissue culture procedure had yielded incorrect results. Histological examination of this accession confirmed the presence of endophyte, as did a subsequent tissue culture test. With two other infected accessions, diagnostic amplification products were not detected with several assays, even though histological examination confirmed the presence of endophyte. With DNA from several barley accessions infected with Neotyphodium endophytes (7), a diagnostic amplification product was not formed with either the Tub 2 or the 11-1 and 11-2 primers. In addition, a Kentucky 31 derivative originally used in our tests as an E- control was found, through histological examination, to possess an endophytic fungus other than a Neotyphodium sp. DNA from this accession also gave a negative response with both pairs of primers. These results suggested that the PCR-based assay using the Tub-2 primers was specific for Neotyphodium endophytes of tall fescue.

The PCR-based technique has some advantages over other methods used for endophyte detection. It is rapid, requiring only a day to screen 60 or more plants. It is also sensitive and requires only a few milligrams of tissue. Unlike the methods that require skills in endophyte identification, the PCRbased method is easy to learn and can provide reliable results even if persons carrying out the test have no previous experience with endophytes. Finally, this technique should be useful for detecting Neotyphodium spp. in tall fescue accessions that harbor genetically diverse endophytes.

The PCR-based technique does have some pitfalls. False positives are not observed if the usual care is taken to avoid DNA contamination. However, we have occasionally encountered false negatives, which presumably arise, in at least some cases, because the fungus is not uniformly present in the sampled tissue. For this reason, it is important to repeat DNA extraction and amplification with any plant scored as E- in the first round of testing, and to sample tissue from several grass tillers. Alternatively, testing could be carried out on duplicate or triplicate samples of all plants. It is also important, as a check on the DNA extraction procedure, to include in each set of samples grass tissue known to be either endophyte-free or endophyte-infected. In addition, an extract of DNA that can act as a template for synthesis of the diagnostic amplification product should be included in each set of amplification reactions.

Groppe and Boller (12) recently described a PCR assay for Epichlöe-type endophytes that used primers based on the nucleotide sequence of a variable microsatellite region in the genomic DNA from Epichlöe spp. Although in planta detection of Neotyphodium endophytes in tall fescue was not demonstrated with these primers, amplification products were obtained when DNA isolated from several Neotyphodium spp. was used as a template, and it is likely that these microsatellite-derived primers could also be used for detection of Neotyphodium endophytes in tall fescue tissue. However, the anomalous response to changes in annealing temperature observed when such primers were used with several Neotyphodium isolates suggests that optimization of PCR conditions could be difficult.

In general, PCR-based methods for detection of fungal endophytes of grasses provide a convenient means of ascertaining infection status. The Tub-2 primers described in this report were superior to the 11-1 and 11-2 primers described earlier (9) in detecting Neotyphodium endophytes in tall fescue accessions from a diverse geographic range.

\section{ACKNOWLEDGMENTS}

We thank M. Azevedo for carrying out histological examination of some of the tall fescue genotypes.

\section{LITERATURE CITED}

1. Bacon, C. W., and Siegel, M. R. 1988. Endophyte parasitism of tall fescue. J. Prod. Agric. 1:45-55.

2. Bacon, C. W., and White, J. F., Jr. 1994. Stains, media and procedures for analyzing endophytes. Pages 47-56 in: Biotechnology of Endophytic Fungi of Grasses. C. W. Bacon and J. F. White, Jr., eds., CRC Press, Boca Raton, FL.

3. Buckner, R. C. 1985. The fescues. Pages 233240 in: Forages: The Science of Grassland. M. E. Heath, R. F. Barnes, and D. S. Metcalfe, eds., Iowa St. Univ. Press, Ames.

4. Christensen, M. J., Leuchtmann, A., Rowan, D. D., and Topper, B. A. 1993. Taxonomy of Acremonium endophytes of tall fescue (Festuca arundinacea), and perennial rye grass (Lolium perenne). Mycol. Res. 97:10831092.

5. Clark, E. M., White, J. F., and Patterson, R. M. 1983. Improved histochemical techniques for the detection of Acremonium coenophialum in tall fescue and methods for in vitro culture of the fungus. J. Microbiol. Methods 1:149-155.

6. Clement, S. L., Graves, W., Cunningham, P., Nebling, V., Bounejmate, W., Saidi, S., Baya, B., Chakroun, M., Mezni, A., and Porqueddu, C. 1997. Acremonium endophytes in Mediterranean tall fescue. Pages 49-51 in: Neotyphodium/Grass Interactions, C. W. Bacon and N. S. Hill, eds., Plenum Press, New York.

7. Clement, S. L., Wilson, A. D., Lester, D. G., and Davitt, C. M. 1997. Fungal endophytes of wild barley and their effects on Diuraphis noxia population development. Entomol. Exp. Appl. 82:275-281.

8. Conger, B. V., and McDaniel, J. K. 1983. Use of callus cultures to screen tall fescue samples for Acremonium coenophialum. Crop Sci. 23:172-174.

9. Doss, R. P., and Welty, R. E. 1995. A polymerase chain reaction-based procedure for detection of Acremonium coenophialum in tall fescue. Phytopathology 85:913-917.

10. Garthwaite, I. Cellular and molecular techniques for characterizing Neotyphodium/grass interactions. Pages 361-376 in: Neotyphodium/Grass Interactions. C. W. Bacon and N. S. Hill, eds., Plenum Press, New York.

11. Glenn, A. E., Bacon, C. W., Price, R., and Hanlin, R. T. 1996. Molecular phylogeny of Acremonium and its taxonomic implications. Mycologia 88:369-383

12. Groppe, K., and Boller, T. 1997. PCR assay based on a microsatellite-containing locus for detection and quantification of Epichlöe endophytes in grass tissue. Appl. Environ. Microbiol. 63:1543-1550.

13. Gwinn, K. D., Collins-Shepard, M. H., and Reddick, B. B. 1991. Tissue print-immunoblot, an accurate method for the detection of Acremonium coenophialum. Phytopathology 81:747-748

14. Johnson, M. C., Pirone, T. P., Siegel, M. R., and Varney, D. R. 1982. Detection of Epichlöe typhina in tall fescue by means of enzyme-linked immunosorbent assay. Phytopathology 72:647-650.

15. Leuchtmann, A., and Clay, K. 1990. Isozyme variation in Acremonium/Epichlöe fungal endophyte complex. Phytopathology 80:11331139.

16. Morgan-Jones, G., and Gams, W. 1982. Notes on Hypomycetes. XLI. An endophyte of Festuca arundinacea, and the anamorph of Epichlöe typhina, a new taxa in one of two new sections of Acremonium. Mycotaxon 15:311-318.

17. Reddick, B. B., and Collins, M. H. 1988. An improved method for detection of Acremonium coenophialum in tall fescue plants. Phytopathology 78:418-420.

18. Saiki, R. K., Gelfand, D. H., Stoffel, S. Scharf, S. J., Higuchi, R., Hort, G. T., Mullis, K. B., and Erlich, H. A. 1988. Primer directed enzymatic amplification of DNA with thermo stable DNA polymerase. Science 239:487491.

19. Sambrook, J., Fritsch, E. F., and Maniatis, T. 1989. Molecular Cloning: A Laboratory Manual. Cold Spring Harbor Laboratory Press, Cold Spring Harbor, NY.

20. Schardl, C. L. 1996. Epichlöe species: fungal symbionts of grasses. Annu. Rev. Phytopathol. 34:109-130

21. Schardl, C. L., and Phillips, T. D. 1997. Protective grass endophytes. Where are they and where are they going? Plant Dis. 81:430-438.

22. Siegel, M. R., Johnson, M. C., Varney, D. R., Nesmeth, W. C., Buckner, R. C., Bush, L. P., Burrus, P. B., Jones, T. A., and Boling, J. A. 1984. The fungal endophyte in tall fescue: Incidence and dissemination. Phytopathology 74:932-937.

23. Stewart, C. N., Jr., and Via, L. E. 1993. A rapid CTAB isolation technique useful for RAPD finger printing and other PCR applications. Biotechniques 14:748-749, 751.

24. Tsai, H-F., Liu, J-S., Staben, C., Christensen, J., Latch, G. C. M., Siegel, M. R., and Schardl, C. L. 1994. Evolutionary diversification of fungal endophytes of tall fescue grass by hybridization with Epichlöe species. Proc. Natl. Acad. Sci. USA 91:2542-2546.

25. Welty, R. E., Azevedo, M. D., and Cook, K. L. 1986. Detecting viable Acremonium endophytes in leaf sheaths and meristems of tall fescue and perennial ryegrass. Plant Dis. 70:431-435.

26. White, J. F., Jr., and Morgan-Jones, G. 1987. Endophyte-host associations in forage grasses. X. Cultural studies on some aspects of Acremonium sect Albolanosa, including a new species, A. starrii. Mycotaxon 30:87-95. 